\title{
THE LEVEL PREPAREDNESS HEAD OF FAMILY FOR FACING THE EARTHQUAKE DISASTER SUB-DISTRICT IMOGIRI AND JETIS IN BANTUL DISTRICT
}

\author{
Niken Setyaningrum ${ }^{1)}$, Andri Setyorini ${ }^{2)}$ \\ 1.2) Sekolah Tinggi Ilmu Kesehatan Surya Global Yogyakarta \\ Corresponding e-mail : nikensetyaningrum7@gmail.com
}

\begin{abstract}
BACKGROUND : Indonesia is one of the countries in the world that is vulnerable to various natural disasters. Indonesia is located at the confluence of three main plates of the earth, the Eurasian Plate, the Indo-Australian Plate and the Pacific Plate. One of the disasters that occurred in Indonesia was an earthquake, Yogyakarta is an area prone to experiencing earthquakes more precisely in Bantul district. In 2006 the earthquake in Yogyakarta claimed more than 6500 lives and property losses. The main factor in the emergence of many victims due to disaster is due to lack of knowledge about disasters and lack of preparedness in anticipating the disaster. The purpose of this study was to measure the preparedness of the head of the family for the earthquake disaster in Imogiri and Jetis sub-districts of Bantul Regency.

SUBJECT AND METHODE : This type of research is in the form of quantitative descriptive by describing data that has been collected without intending to make conclusions that do not apply to the public. The number of samples is 192 head familys. Sampling of research using acidental sampling for the selection of male head family respondents. The instruments used were LIPI and UNESCO in 2006.

RESULTS : The results of research on the level of disaster preparedness in the majority Imogiri districts in the ready category (65-79) were 93 respondents $(96.9 \%)$, while the jetis sub-district included in the ready category (65-79) 95 respondents (99\%). There is no difference in the level of preparedness between the imogiri and the jetis sub-district with a sig value of 0.313 .

CONCLUSION : Suggestions from this research are to improve disaster preparedness by conducting training and simulations from the government, BPBD or involving health education institutions.
\end{abstract}

Keywords: Preparedness, Disasters, Earthquakes, Head of Family

\section{BACKGROUND}

Indonesia as one of the Asia-Pacific countries is the country with the second largest disaster risk in the world. This is because the entire Indonesian archipelago is vulnerable to disasters (BNPB, Disaster Preparedness Guide for Families, 2018). Indonesia is located in the path of the meeting of 3 world tectonic plates, namely the Indo Australian Plate, the Eurasian Plate and the Pacific Plate. The movements of these three plates have different speeds. Tectonic plates in Indonesia are still mostly active, these plates have different directions of movement, namely the Eurasian plate which moves relative to the southeast, the Indo-Australian Plate which moves relative to the north, and the Pacific plate which relatively moves to the west. The collision between the plates that are always moving is what causes earthquakes, earthquakes caused by collisions between these plates are also called 
tectonic earthquakes. As a result of the collision of the plates formed a subduction line (subduction zone) (Sukandarrumidi, 2010). Based on data from the Yogyakarta Regional Disaster Management Agency (BPBD), the 2006 earthquake caused more than 5800 deaths, 37,000 people were injured, 84,000 houses were razed to the ground, and more than 200,000 houses suffered minor, moderate or severe damage. An earthquake is a shock that is quickly earthed due to faults or shifts in soil slabs (Buana \& Utomo, 2017). Earthquakes are natural disasters that cannot be accurately predicted, even so far there are no tools that can detect these earthquakes. Considering that the earthquake was a devastating disaster and not a few casualties and building damage due to the earthquake. Disaster management is a method used for disaster management, this disaster management is effective in minimizing casualties and also damage to buildings, and existing facilities. One of the stages of disaster management is Preparedness (Rini, 2017). Disaster management is an integral part of national development in order to carry out the mandate of the 1945 Constitution, as referred to in paragraph IV of the opening of the 1945 Constitution. In its implementation, disaster management is the duty and responsibility of the government and regional government together with the wider community. The form of responsibility includes meeting the needs of the community caused by disaster which is one form of state protection for citizens.

Natural disasters are events that are caused by natural hazards that may be the result of several factors, including internal factors (under the earth's surface), such as plate movements, external / topographic factors (topography) such as land contours, weather factors (meteorology or hydrology) ), and biological phenomenon factors (Buana \& Utomo, 2017). Preparedness is an effort made to anticipate disasters through organizing appropriate and efficient steps. It is intended that residents have better preparation for facing disasters (BNPB, 2016). Preparedness aims to minimize the side effects of hazards through effective, timely, adequate, efficient preventive measures for emergency response measures and disaster relief. Paramenter is a measure that is assessed to measure something. In preparedness there are several parameters to measure preparedness. Based on parameters from LIPI and UNESCO, 2006 (Sopaheluwakan, 2006).

The community preparedness framework is used as a tool to assess the extent of community preparedness in an area. The parameters that become the reference in the framework of preparedness to deal with earthquake-tsunami disasters, including knowledge and attitudes towards disaster; emergency response plan; disaster warning system; resource mobilization (Hidayati, Ngadi, Purwaningsih, \& Soekarno, 2008). One element in society is the head of the family. The head of the family is the person who acts as a leader in the family (Buana \& Utomo, 2017).

Families are expected to have the ability to cope with earthquakes, because the family's role in preparedness is very important. The head of the family plays a role in conveying information to his family, making decisions that can quickly affect his family members and also the head of the family as a source of social support for his family, due to the influence of all his words, behavior and actions will be modeled by his family (Rini, 2017). Utilization of knowledge as a product can encourage knowledge users to be able and independent to support the resolution of the problems they face.

Knowledge is developed through a process of experience in which the knowledge is used. Therefore, to minimize the risk of disaster must be an integrated part with the head of the family. Based 
on data from the Yogyakarta Regional Disaster Management Agency (BPBD), the 2006 earthquake caused more than 5800 deaths, 37,000 people were injured, 84,000 houses were razed to the ground, and more than 200,000 houses suffered minor, moderate or severe damage. Much damage occurred in Imogiri and Jetis Districts. Therefore the researcher wants to know the frequency distribution of the level of preparedness of the head of the family related to the earthquake disaster and to know whether there are differences in the level of preparedness in Imogiri and Jetis Districts.

\section{METHODE}

This type of research was quantitative with the design used in this study is descriptive by describing the data that has been collected without intending to make conclusions that apply to the public. The population in this study were all head of families in Imogiri sub-district 17,670 and Jetis subdistrict 15,755 . The sample in this study was head of families heads with male sex, based on creative tables the number of samples was 192 respondents. Sampling technique with accidental sampling for the selection of head of families. Instructions in the form of questionnaires refer to (Sopaheluwakan, 2006) in the form of structured questionnaires and interviews. Preparedness is grouped into four parameters namely knowledge and attitudes / Knowledge and Attitude (KA), emergency planning (Emergency) (EP), warning system / Warning System (WS) and resource mobilization (RMC). Readiness index is formulated as follows:

Preparedness Index $=\frac{\text { Real Total Parameters }}{\text { Parameter Maximum Score }} \times 100 \%$

Table 1. Categories of readiness index values

\begin{tabular}{ccc}
\hline No & Index Value & Category \\
\hline 1 & $80-100$ & Very Ready \\
2 & $65-79$ & Ready \\
3 & $55-64$ & Almost Ready \\
4 & $40-54$ & Less Ready \\
5 & $0-39$ & Not Ready \\
\hline
\end{tabular}

\section{RESULTS AND DISCUSSION}

Research results can be seen from the table below:

Table 2. Characteristics of respondents based on age, occupation and education (Primary Data, 2019)

\begin{tabular}{llcccc}
\hline \multirow{2}{*}{ Characteristics of Respondents } & \multicolumn{2}{c}{ Imogiri sub-distric } & \multicolumn{2}{c}{ Jetis sub-distric } \\
\cline { 3 - 6 } & & $\mathrm{f}$ & $\%$ & $\mathrm{f}$ & $\%$ \\
\hline Age & 5 & 5,2 & 10 & 10,4 \\
& $26-35$ years old & 33 & 34,4 & 37 & 38,5 \\
$36-45$ years old & 43 & 44,8 & 36 & 37,5 \\
$46-55$ years old & 15 & 15,6 & 13 & 13,5 \\
$56-65$ years old & & & & \\
\hline
\end{tabular}




\begin{tabular}{lcccc}
\hline Occupation & & & & \\
Does Not Work & 2 & 2,1 & 2 & 2,1 \\
Farmer & 18 & 18,8 & 16 & 16,7 \\
Government employees & 11 & 11,5 & 11 & 11,5 \\
& & & & \\
\hline Private employees & 21 & 21,9 & 26 & 27,1 \\
Entrepreneur & 18 & 18,8 & 18 & 18,8 \\
Trader & 26 & 27,1 & 23 & 24 \\
Education & & & & \\
No school & 3 & 3,1 & 2 & 2,1 \\
Elementary school & 20 & 20,8 & 18 & 18,8 \\
Junior high school & 20 & 20,8 & 18 & 18,8 \\
Senior high school & 29 & 30,2 & 34 & 35,4 \\
College & 24 & 25 & 24 & 25 \\
\hline
\end{tabular}

Based on data describing the characteristics of respondents in the Imogiri sub-district, the majority of respondents in the range of $46-55$ years of age are 43 respondents, while for the majority of sub distric, the age range is $36-45$ years, amounting to 37 respondents. The occupation that is mostly done in the Imogiri sub-district and if the majority of the profession are both private employees. The level of responsive education also shows the same results in the two regions where the majority of education is Senior high school.

Table 3. Disaster Knowledge in Imogiri and Jetis Sub-Districts (Primary Data, 2019)

\begin{tabular}{|c|c|c|c|c|}
\hline \multirow{2}{*}{ Knowledge and Attitude (KAP) } & \multicolumn{2}{|c|}{ Imogiri sub-distric } & \multicolumn{2}{|c|}{ Jetis sub-distric } \\
\hline & $f$ & $\%$ & $f$ & $\%$ \\
\hline Very Ready & 20 & 20,8 & 47 & 49,0 \\
\hline Ready & 76 & 79,2 & 49 & 51,0 \\
\hline Almost Ready & 0 & 0 & 0 & 0 \\
\hline Less Ready & 0 & 0 & 0 & 0 \\
\hline Not Ready & 0 & 0 & 0 & 0 \\
\hline Total & 96 & 100 & 96 & 100 \\
\hline
\end{tabular}

The results of the frequency distribution of the level of knowledge about the majority of disasters fall into the ready category, which ranges from 65 to 79 as many as 76 respondents in the Imogiri sub-district and 49 respondents in the jetis sub-district

Based on data on the frequency distribution of family and disaster preparedness plans, the majority of the two places shows the same category, which is ready for the range of 65-79 with 77 respondents from Imogiri sub-district and 62 respondents from Jetis sub-district. 
Table 4. Family and Disaster Preparedness Plans in Imogiri and Jetis Districts (Primary data, 2009)

\begin{tabular}{|c|c|c|c|c|}
\hline \multirow{2}{*}{ Emergency planning (EP) } & \multicolumn{2}{|c|}{ Imogiri sub-distric } & \multicolumn{2}{|c|}{ Jetis sub-distric } \\
\hline & $f$ & $\%$ & $f$ & $\%$ \\
\hline Very Ready & 0 & 0 & 0 & 0 \\
\hline Ready & 77 & 80,2 & 62 & 64,6 \\
\hline Almost Ready & 19 & 19,8 & 34 & 35,4 \\
\hline Less Ready & 0 & 0 & 0 & 0 \\
\hline Not Ready & 0 & 0 & 0 & 0 \\
\hline Total & 96 & 100 & 96 & 100 \\
\hline
\end{tabular}

Table 5. Disaster Warning in Imogiri District and Jetis District (Primary Data, 2019)

\begin{tabular}{cccccc}
\hline \multirow{2}{*}{ Warning System (WS) } & \multicolumn{2}{c}{ Imogiri sub-distric } & \multicolumn{2}{c}{ Jetis sub-distric } \\
\cline { 3 - 6 } & Very Ready & $\mathrm{f}$ & $\%$ & $\mathrm{f}$ & $\%$ \\
\hline Ready & 59 & 61,5 & 51 & 53,1 \\
& Almost Ready & 37 & 38,5 & 45 & 46,9 \\
& Less Ready & 0 & 0 & 0 & 0 \\
& Not Ready & 0 & 0 & 0 & 0 \\
& & 0 & 0 & 0 & 0 \\
\hline Total & 96 & 100 & 96 & 100 \\
\hline
\end{tabular}

The results of the majority frequency distribution showed that the category of highly prepared ranges from 80-100 in Imogiri subdistrict with 59 respondents and jetis sub-district with 51 respondents.

Table 6. Resource Mobilization in Imogiri District and Jetis District (Primary Data, 2019)

\begin{tabular}{cccccc}
\hline \multirow{2}{*}{ Resource Mobilization (RMC) } & \multicolumn{2}{c}{ Imogiri sub-distric } & \multicolumn{2}{c}{ Jetis sub-distric } \\
\cline { 3 - 6 } & Very Ready & $\mathrm{f}$ & $\%$ & $\mathrm{f}$ & $\%$ \\
\hline Ready & 0 & 0 & 0 & 0 \\
& Almost Ready & 54 & 56,3 & 60 & 62,5 \\
& Less Ready & 40 & 41,7 & 32 & 33,3 \\
& Not Ready & 2 & 2,1 & 4 & 4,2 \\
& & 0 & 0 & 0 & 0 \\
\hline Total & 96 & 100 & 96 & 100 \\
\hline
\end{tabular}

Based on the data distribution of the frequency of resource mobilization, the majority of categories are in the range of 65-79, 54 respondents in Imogiri sub-district and 60 respondents in jetis sub-district. There are 4 respondents in the sub-district of jetis in the category of less prepared as many as 4 respondents. 
Table 7. Preparedness Levels in Imogiri and Jetis Districts (Primary Data, 2019)

\begin{tabular}{|c|c|c|c|c|}
\hline \multirow{2}{*}{ Level of Preparedness } & \multicolumn{2}{|c|}{ Imogiri sub-distric } & \multicolumn{2}{|c|}{ Jetis sub-distric } \\
\hline & $f$ & $\%$ & $f$ & $\%$ \\
\hline Very Ready & 0 & 0 & 0 & 0 \\
\hline Ready & 93 & 96,9 & 95 & 99,0 \\
\hline Almost Ready & 3 & 3,1 & 1 & 1,0 \\
\hline Less Ready & 0 & 0 & 0 & 0 \\
\hline Not Ready & 0 & 0 & 0 & 0 \\
\hline Total & 96 & 100 & 96 & 100 \\
\hline \multicolumn{5}{|c|}{$\begin{array}{l}\text { Based on the overall frequency distribution the majority level of prepe } \\
93 \text { respondents in Imogiri sub-district and } 95 \text { respondents in jetis sub-district. }\end{array}$} \\
\hline \multicolumn{5}{|c|}{ Table 8. Differences in Disaster Preparedness Levels in Imogiri and Jetis Sub-Districts (Primary Data, 2019) } \\
\hline Variabel & & & & Sig \\
\hline Level of Preparadness imogiri sub distric & & & & 0,313 \\
\hline Level of Preparadness Jetis sub distric & & & & \\
\hline
\end{tabular}

The results of the bivariate test using Mann Whitney showed that there were no differences in the level of earthquake preparedness in Imogiri and Jetis sub-districts with a sig value of 0.313 .

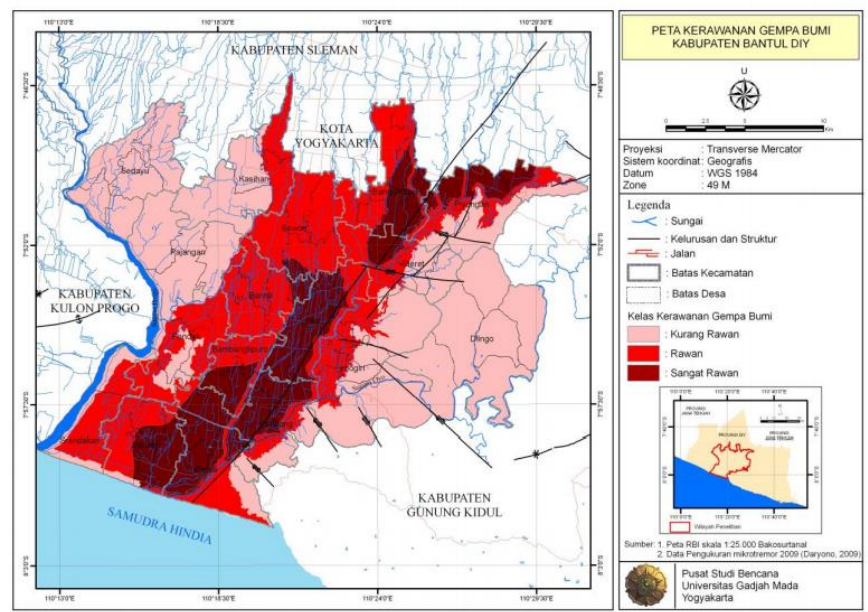

Figure 1. Disaster-prone map of Bantul Distric (Source: UGM Center for Disaster Studies, 2009)

Bantul distric is a legitimate regency in Yogyakarta, based on disaster prone maps, there are several districts that are very at risk of disaster. In this research, the locations used are Imogiri and Jetis sub-districts. Both of these locations have almost the same characteristics as the frequency distribution in the Imogiri sub-district, the majority of ages are in the early elderly category, namely the range (46-55 years), while the jetis massuk subdistrict is in the late adult category (36-45 years). The majority of the level of education in the Imogiri and Jetis sub-districts are both at the high school level, while for occupations there are professional differences, the 
majority in the Imogiri sub-district as traders and in the Jetis sub-district as private employees. Based on research (Suwaryo \& Yuwono, 2017), the results show that there is a significant relationship between age, education, occupation and level of knowledge. The more old enough, the more mature level someone will be more mature in thinking and working. This also affects the cognitive of a person. Then, in terms of public trust, someone more mature will be more trusted than someone who is not yet mature enough. A person's age also affects the person's comprehension and mindset. As you get older you will also develop your grasp and mindset, so that the knowledge you get is better.

According to (Carter, 2011), the higher the level of education a person is, the easier it will be to receive information so that the more experience he has, in this case especially knowledge about natural disaster mitigation. Someone who has extensive experience will have an impact on his cognitive. Education is an increasingly important factor in everyday life. The level of education will affect one's perception of cognitive. Someone who is highly educated also has high reasoning too.

Research conducted by (Pangesti, 2012), explains that one's work will affect one's knowledge and experience. The reason why work affects someone is when the job uses the brain more often than it uses muscles. The performance and ability of one's brain in storing (memory) increases or increases when used frequently, this is directly proportional when one's work uses the brain more than muscle. Another explanation that supports a person's brain or cognitive ability will increase when often used to indulge in and do things in the form of puzzles or reasoning. Earthquake disaster preparedness consists of 4 aspects, namely knowledge of disasters, family and disaster preparedness plans, disaster warnings, resource mobilization. In this study each aspect obtained frequency distribution data for knowledge about disasters in the two regions included in the ready category, but 76 respondents (79.2\%) imogiri districts more than in jetis district that is 49 respondents $(51.0 \%)$, knowledge gained from several components, namely family knowledge in getting information related to disasters whether it comes from TV, radio, newspapers or magazines. Government involvement is very important for disaster mitigation in increasing disaster-related knowledge in collaboration with BPBD in Bantul and central districts. The second point is the family preparedness plan in the disaster of the majority of the two districts included in the ready category. At this point the family prepares important documents for medicines and important cellphone numbers that can be contacted during an earthquake. Most respondents answered that they have not yet conducted evacuation drills or simulations. The third point is included in the ready category (65-79) but there are still many who fall into the category of almost ready is a disaster warning to know the signs of the majority of disasters are still traditionally, while the sources obtained are through the government with TV media, but many have not prepared food, clothing, medicines, important documents etc. The fourth point is the mobilization of resources into the ready category (65-79). The majority have not yet participated in first aid training, evacuation of victims, water treatment and food processing. In general, the two sub-districts fall into the ready category, because the characteristics of respondents are almost the same there is no difference in the overall level of disaster preparedness. To improve preparedness, one of the roles that cannot be ruled out in handling natural disasters is government, both local and central.

\section{CONCLUSION AND RECOMMENDATION}

The conclusion of the study are: 
1. The level of disaster preparedness in the majority Imogiri sub-districts in the ready category (65-79) was 93 respondents (96.9\%), while the jetis sub-district included in the ready category (65-79) as many as 95 respondents $(99 \%)$.

2. There is no difference in the level of preparedness between the imogiri sub-district and the jetis subdistrict with a sig value of 0.313 .

From the results above we recommend that :

1. Increase knowledge about earthquake and tsunami disaster preparedness because the target of the government is in the category of very ready, the regions in the Imogiri and Jetis sub-districts increase knowledge related to disasters, preparedness plans, warning of disasters and mobilization of resources by conducting training and simulations.

2. The government and BPBD provide training and routine simulations to the public.

3. Involving educational institutions especially in the health sector in providing training and simulations.

\section{REFERRENCE}

BNPB. (2016). Perka BNPB No:4 Th 2008 tentang Pedoman Penyusunan Rencana Penanggulangan

Bencana. https://bpbd.sumbarprov.go.id/details/news/37 Diakses 14 Agustus 2019.

BNPB. (2018). Panduan Kesiapsiagaan Bencana Untuk Keluarga. https://siaga.bnpb.go.id/hkb/pocontent/uploads/documents/Buku_Pedoman_Kesiapsiagaan_Keluarga_FA_A5.pdf Diakses tanggal 1 Agustus 2019.

Buana, C. F., \& Utomo, H. (2017). Pedoman Standar Layanan Kesiapan Keluarga Hadapi Bencana. https://www.kemenpppa.go.id/lib/uploads/list/54be0-buku-pedoman-standar-layanankesiapan-keluarga-hadapi-bencana.pdf Diakses tanggal 18 Agustus 2018.

Carter, W. (2011). Disaster Manegement: A Disaster Manager's Handbook. Manila: ADB.

Fahrevy, Sari, S. A., \& Indra. (2014). KAJIAN TINGKAT PENGETAHUAN KEPALA KELUARGA DALAM MENGHADAPI BENCANA GEMPA BUMI DI KECAMATAN BAITUSSALAM KABUPATEN ACEH BESAR. Cakradonya Dent J, http://www.jurnal.unsyiah.ac.id/CDJ/article/download/10430/8208 Diakses 21 Agustus 2019.

Hidayati, D., Ngadi, S., Purwaningsih, \& Soekarno. (2008). Kesiapsiagaan Masyarakat dalam Mengantisipasi Bencana Alam di Kabupaten Cilacap. LIPI Press, ISBN : 978-979-799-287-3. 
Pangesti, A. D. (2012). Gambaran tingkat pengetahuan dan aplikasi kesiapan bencana pada mahasiswa fakultas ilmu keperawatan universitas indonesia tahun 2012. Jakarta: Skripsi.

Pusat Studi Bencana UGM. (2009). Peta Kerawanan Gempa Bumi Kabupaten Bantul. Bantul: https://sosial.bantulkab.go.id/filestorage/dokumen/2014/08/Peta\%20Kerawanan\%20Gempa\% 20Bumi.pdf Diakses 26 Agustus 2019.

Rini, E. P. (2017). TINGKAT PEMAHAMAN KESIAPSIAGAAN KEPALA KELUARGA DALAM MENGHADAPI BENCANA GEMPA BUMI DI DUSUN POTROBAYAN DESA SRIHARDONO KECAMATAN PUNDONG KABUPATEN BANTUL. https://eprints.uny.ac.id/53084/19/File\%20TAS\%20Jurnal\%2013416241033.pdf.

Sopaheluwakan, J. (2006). Kajian Kesiapsiagaan Masyarakat Dalam Mengantisipasi Bencana Gempa $\begin{array}{llll}\text { Bumi dan } & \text { Tsunami. LIPI- UNESCO http://www.buku- }\end{array}$ e.lipi.go.id/utama.cgi?lihatarsip\&jans001\&1273262299\&2 Diakses tanggal 18 Agustus 2018.

Sukandarrumidi. (2010). Bencana Alam \& Bencana Anthropogene. Yogyakarta: Kanisius.

Suwaryo, P. A., \& Yuwono, P. (2017). Faktor-Faktor Yang Mempengaruhi Tingkat Pengetahuan Masyarakat dalam Mitigasi Bencana Alam Tanah Longsor. The 6th University Research Colloquium Universitas Muhammadiyah Magelang, http://journal.ummgl.ac.id/index.php/urecol/article/download/1549/761/ Diakses 21 Agustus 2019. 